\title{
A Taste Preference Study in Pediatric Patients: Paracetamol and Ibuprofen
}

\section{Elif Aksöz ๑ Selçuk Yazıcı ๑ Oğuzhan Korkut (1) Nebahat Yılmaz (1) Tanju Çelik ®}

\section{Pediyatrik Hastalarda Bir Tat Tercihi Çalışması: Parasetamol ve ibuprofen}

\begin{abstract}
Objective: Ibuprofen and paracetamol are two of the most commonly used medicines to treat fever in children. In pediatric patients, good taste is the most important factor for completing treatment. Taste preferences might differ in children from different cultures and countries. The aim of this study is to determine the preparations of paracetamol and ibuprofen preferred in terms of taste and smell in the treatment of children on an ambulatory basis in Turkey.

Method: In this study, two different paracetamol and two different ibuprofen liquid formulations were evaluated. The study population consisted of 145 children (71 girls, 74 boys) with a complaint of fever at a mean age of $5.69 \pm 2.93$ years. A questionnaire was prepared for assessing the demographic variables and compliance and a "5-point facial hedonic scale" was added to the form for evaluating the taste and smell of drugs by children. After the end of treatment parents filled out the forms completely and brought them back during the check-up examination.

Results: There was no statistically significant difference between the taste and smell preference of different paracetamol or ibuprofen preparations. However, the increase in taste and smell scores was accompanied with a significant decrease for the need of additional nutrients and spitting behavior.

Conclusion: As a conclusion all of paracetamol, and ibuptofen preparations are generally acceptable as for their taste and smell. However, prescribing the children a palatable antipyretic will decrease the difficulties experienced by their parents and increase the compliance of the patient to the medicine.
\end{abstract}

Keywords: Child, paracetamol, ibuprofen, taste, smell

öz

Amaç: ibuprofen ve parasetamol, çocuklarda yüksek ateş tedavisi için en sık kullanılan ilaçlardır. Pediatrik hastalarda, ilacın tadının sevilmesi tedaviyi tamamlamak için en önemli faktördür. Tat tercihleri, farklı kültür ve ülkelerdeki çocuklarda farklı olabilir. Bu çalışmanın amacı, Türkiye'de ayakta tedavi gören çocuklarda tat ve koku açısından hangi parasetamol ve ibuprofen preparatlarının tercih edildiğini belirlemektir. Yöntem: Bu çalışmada, iki farklı parasetamol ve iki farklı ibuprofen sıvı formülasyonu değerlendirilmiştir.

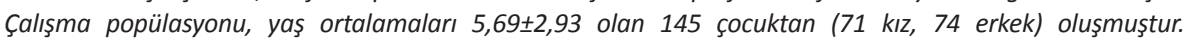
Demografik değişkenlerin ve uyumluluğun değerlendirilmesi için bir anket hazırlanmış ve çocukların ilaçların tadı ve kokusunu değerlendirmeleri için formda "5 puanlık bir hedonik yüz ölçeği" eklenmiştir. Tedavinin bitiminden sonra ebeveynler tüm formu doldurup kontrol muayenesi sırasında geri getirmişlerdir.

Bulgular: Farklı parasetamol veya ibuprofen preparatlarında, tat ve koku tercihleri arasında istatistiksel olarak anlamlı bir fark bulunmamıştır. Bununla birlikte, tat ve koku puanları artıkça, ek besin gereksinimi ve tükürme davranışında önemli bir düşüş görülmüştür.

Sonuç: Sonuç olarak, ibuprofen veya parasetamol preparatlarının tamamı, lezzet açısından genel olarak kabul edilen ilaçlardır. Sonuçta, bir çocuk için hoşa giden tadı olan antipiretik bir ilaç reçete edilmesi, ilacı verirken ebeveynlerin yaşadığı zorlukları azaltacak ve hastanın ilaç uyumunu artıracaktır.
Alındığı tarih: 02.05.2018

Kabul tarihi: 22.10.2018

Online Yayın tarihi: 14.03.2019

Elif Aksöz

Balıkesir Üniversitesi Tıp Fakültesi, Tıbbi Farmakoloji Anabilim Dalı,

Çağış Kampüsü,

Balıkesir, Türkiye

aksoz@balikesir.edu.tr ORCID: 0000-0002-4827-804X

S. Yazıcı 0000-0002-6526-9460 Balıkesir Üniversitesi Tıp Fakültesi, Çocuk Hastalıkları Anabilim Dalı, Balıkesir, Türkiye

O. Korkut 0000-0002-2057-4197 Balıkesir Üniversitesi Tıp Fakültesi, Tıbbi Farmakoloji Anabilim Dalı, Balıkesir, Türkiye

N. Yilmaz 0000-0002-6711-8498

S. B. Atatürk Şehir Hastanesi, Çocuk Hastalıkları Bölümü, Balıkesir, Türkiye

T. Çelik 0000-0003-3522-9406 S. B. Dr Behcet Uz Çocuk Hastanesi, Çocuk Hastalıkları Bölümü, izmir, Türkiye

This study was presented as a poster presentation at the $23^{\text {th }}$ National Congress of the Turkish Pharmacology Society, 7-10 September 2015, Ankara, Turkey.

Anahtar kelimeler: Çocuk, parasetamol, ibuprofen, tat, koku 


\section{INTRODUCTION}

Fever is one of the most common reasons for referral to pediatricians and medication use (1). Guidelines recommend treatment of febrile children at home unless the presence of a serious underlying problem. Paracetamol or ibuprofen is recommended for the medical treatment of fever in the current guidelines ${ }^{(2,3)}$. According to the pediatricians, good taste of a drug and ease in swallowing, determine the difference between success and failure in treatment ${ }^{(4)}$.

Unpleasant taste is reported to be the biggest obstacle for completing treatment in $90 \%$ of the pediatric patients ${ }^{(5)}$. Although there are many studies about medication use and palatability in children, most studies have focused on antibiotics. Furthermore, in some studies, the tastes of medicines manufactured for kids were evaluated in healthy adult volunteers ${ }^{(6)}$. Actually, it ihas been shown that taste preferences of children are different from adults (7). As opposed to adults, children have a higher tendency to choose sweet and salty nutrients. This could be explained by their need for energy and minerals during the rapid stages of growth, relevant to the fact that many edibles rich in energy (eggs, mother's milk, fruits) are tastable ${ }^{(8)}$. A few number of studies have revealed the antipyretic medications preferable in terms of taste and smell by obtaining information directly from children ${ }^{(9-11)}$. However, all of these studies were carried out in localized hospital environment. It was considered that children may be affected by the hospital conditions.

In addition, children from different cultures and countries suggest that taste preferences might differ (12). Bubble gum and grapes are more preferred in USA, citrus, red berries and also liquorice in Europe and Scandinavia ${ }^{(13)}$. In this case, regional and ethnic variations should also be taken into consideration in deciding the taste of the drugs ${ }^{(14)}$.

Against this background the purpose of this study is to answer the research question: "Which preparations of paracetamol and ibuprofen are preferred in terms of taste and smell in ambulatory pediatric patients in our country?"

\section{MATERIALS and METHODS}

\section{Ethics}

The study protocol was approved by the Institutional Ethics Committee of Balikesir University (2013/025).

\section{Procedure}

Our study was conducted in three different centers between the dates of July 2013-July 2014. A questionnaire consisting of 18 questions was prepared in order to reveal which commonly prescribed antipyretic drugs are preferred by children in terms of taste and smell. The demographic characteristics were questioned on the form, as well as the person who administered the medication, previous use of the same medication, spitting or vomiting after intake, whether or not additional nutrients are needed together with the drug and compliance. A "5-point facial hedonic scale" was added to the form for evaluating the taste and smell of drugs by children. The 'facial hedonic scale' and working procedure was announced to each subject's parents by the officials (researcher, doctor or nurse). After taking the medicine, parents were asked to encourage the child answer the questions "How do you like the taste of this medicine ?" and "How do you like the smell of this medicine?" and indicate their preferences by marking the appropriate face on a 5-point facial hedonic scale. If more than one medication has been prescribed the child was told to take antipyretic first not to be affected by the taste of other medications. The parents of the patient to whom antipyretic medication was prescribed were asked to mark the taste and smell scale of the form after the use of the first dose, fill out the entire form after the end of treatment and to bring it back in control. When the evaluation forms were brought back, the responses were recorded and were converted to a numeric score: "1- super bad, 2- bad, 3- may be good or may be bad, 4- good, 5super good."

The physician who planned the treatment decided which drug to be prescribed in this study. The researchers did not intervene in the choice of drugs 
and no randomization was performed among the patients.

\section{Participants}

The patients aged 2-11 years, who were referred with a complaint of fever, and whose the treatment will be done at home were included in the study. The patients who had a developmental defect, comorbid chronic disease, a disease that requires hospitalization, and a medical story of allergy to the evaluated drugs were excluded in the study.

\section{Drugs}

Four different widely used antipyretic liquid formulations with different sweeteners and/or flavors, two paracetamol and two ibuprofen in pharmaceutical content, were evaluated in our study. The appropriate dose that fits the child's age and weight was prescribed.

The medicines studied were ibuprofen $100 \mathrm{mg} / 5$ $\mathrm{mL}$ (Zentiva, Istanbul, Turkey and Atabay, Istanbul, Turkey), paracetamol $120 \mathrm{mg} / 5 \mathrm{~mL}$ (GlaxoSmithKline (GSK), Istanbul, Turkey) and paracetamol $250 \mathrm{mg} / 5$ $\mathrm{mL}$ (GSK, Istanbul, Turkey) oral liquids (Table 1).

\section{Data analysis}

The SPSS 15.0 package program was used for statistical analyses. G*Power Version 3.1 was used for calculation of sample size. Minimum sample size for each of the drug group was calculated as 32 by taking Power 0.80 and Effect size 0.30 for df3. The Kruskal-Wallis test was used to determine whether there was a statistically significant difference between the scores given to taste and smell to drugs used in our study. Spearmans' nonparametric correlation analysis was used to evaluate whether there was any relationship between child's age, weight, height, mother's age, mother's and father's education, family income level and taste and smell scores, between scores of taste and smell and additional nutrient utilization, compliance and spitting. The mean age of 4 groups for age was compared with ANOVA. Chi-square tables are made separately for each of the gender and underlying disease status.

\section{RESULTS}

A total of 300 families were reached, of these 186 were brought back the form and 145 went on to have a study and data collected (41 did not fill out the entire form). 74 (51\%) of 145 children included in the study were boys and $71(49 \%)$ were girls, their average age was $5.69 \pm 2.93$ years (Table 2 ). The majority (\% 64.1\%) had received a diagnosis of upper respiratory tract infections (Table 3 ).

Table 2. Descriptive data according to the drug used.

\begin{tabular}{|c|c|c|}
\hline Drug & $\begin{array}{c}\text { Gender } \\
\text { (\%51 M,\%49 F) }\end{array}$ & $\begin{array}{c}\text { Age ( } \pm \text { SD) } \\
(5.69 \pm 2.93)\end{array}$ \\
\hline Ibuprofen (Zentiva-100 mg) & $18 \mathrm{M}, 12 \mathrm{~F}$ & $5.47 \pm 2.60$ \\
\hline Ibuprofen (Atabay-100 mg) & $19 \mathrm{M}, 17 \mathrm{~F}$ & $3.24 \pm 1.09$ \\
\hline Paracetamol (GSK-120 mg) & $19 \mathrm{M}, 25 \mathrm{~F}$ & $5.95 \pm 3.27$ \\
\hline Paracetamol (GSK-250 mg) & $18 \mathrm{M}, 17 \mathrm{~F}$ & $8.06 \pm 1.91$ \\
\hline
\end{tabular}

GSK: GlaxoSmithKline

Table 3. Distribution of the children who participated in the study according to the diagnosis.

\begin{tabular}{lcc}
\hline Diagnosis & Number & $\%$ \\
\hline Upper respiratory tract infections & 93 & 64.13 \\
Lower respiratory tract infections & 12 & 8.27 \\
Urinary tract infections & 6 & 4.13 \\
Other & 34 & 23.44 \\
\hline
\end{tabular}

Table 1. Combinations of drugs used in our study.

\begin{tabular}{llll}
\hline Manufacturer & Active ingredient & Sweetener & Flavor \\
\hline Zentiva & Ibuprofen $100 \mathrm{mg} / 5 \mathrm{ml}$ & Sodium Saccharin, Sorbitol & Citrus oil \\
Atabay & Ibuprofen $100 \mathrm{mg} / 5 \mathrm{ml}$ & Sucrose & Orange Flavor \\
GlaxoSmithKline & Paracetamol $120 \mathrm{mg} / 5 \mathrm{ml}$ & Sorbitol, Sucrose & Strawberry Flavor \\
GlaxoSmithKline & Paracetamol $250 \mathrm{mg} / 5 \mathrm{ml}$ & Sorbitol, Sucrose & Orange Flavor \\
\hline
\end{tabular}


口Taste $\square$ Smell

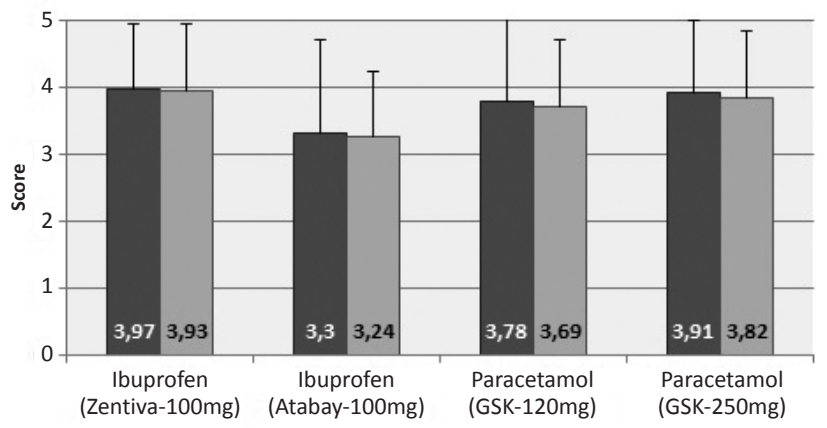

Figure 1. The taste and smell scores of the drugs. GSK: GlaxoSmithKline

There was no statistically significant difference between the taste and smell of different drugs (Figure 1). However, there was a strong positive directional correlation ( $r=0.973)$ between the taste and scent scores of children ( $p=0.001$ ). Although not statistically significant, the favourite drug of children who participated in the study in terms of both taste and scent was ibuprofen syrup (Zentiva) that was orange-scented and contained sucrose and aspartame as sweetener. The least popular medication in terms of both taste and odor scent was an orangeflavored ibuprofen syrup (Atabay) containing sucrose as a sweetener. In the children who participated in the study, with the increase of the scores of taste and smell, spitting behavior and the need for additional nutrients significantly decreased $(p<0.05)$. However, when different medication were used, no statistically significant difference between the spitting behavior and the need for additional nutrients was observed (Figure 2).

Any significant relationship was not observed between the scores of taste and smell and the child's age, weight, height, medication used before, mother's age, mother's and father's education and family income level. There is no difference between the groups in terms of gender, age and underlying disease status.

Although there was not a statistically significant relationship, it was detected that the taste and smell scores of children were compatible with compliance to treatment rates. Rate of compliance to top- rated ibuprofen (Zentiva) was $96.7 \%$, while it was found as

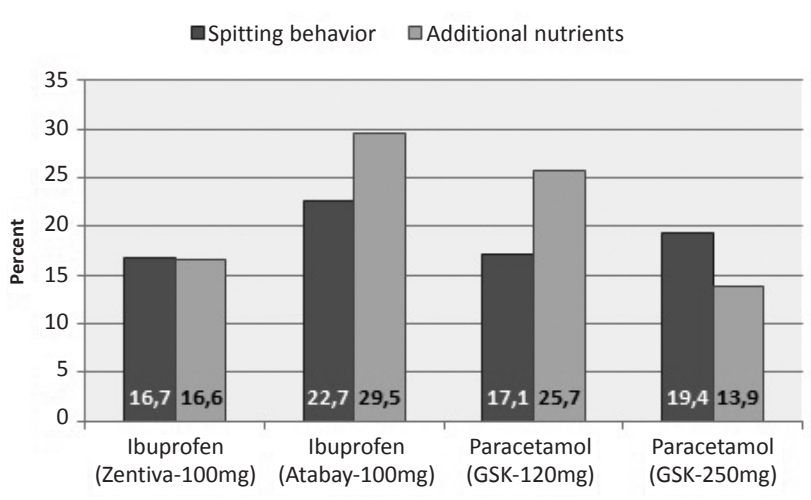

Figure 2. The percent of the need for additional nutrients and the spitting behavior with the drugs. GSK: GlaxoSmithKline

$100 \%$ to the second top-rated medication paracetamol (GSK-250 mg) (Figure 3).

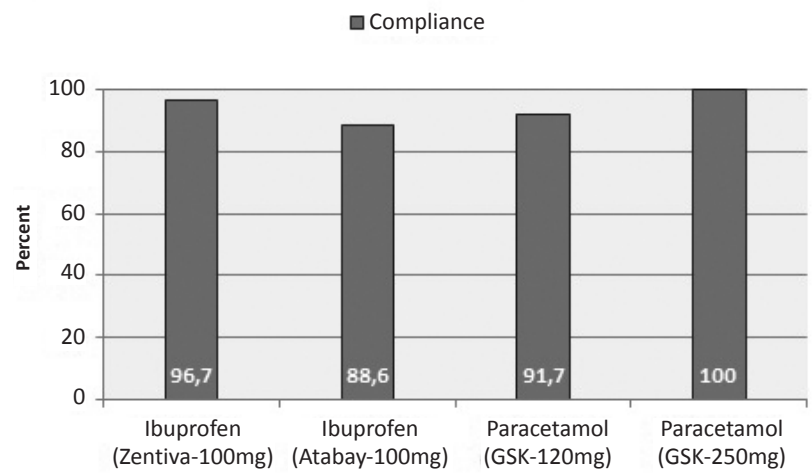

Figure 3. The percent of compliance to the drugs. GSK: GlaxoSmithKline

\section{DISCUSSION}

Four different widely used antipyretic liquid formulations containing paracetamol or ibuprofen were studied in our study. There were no statistically significant difference between preferences of children for these medication in terms of taste and smell. Our results suggest that all ibuprofen and paracetamol preparations are overall easily accepted drugs. Although not statistically significant, interestingly, the most and the least liked drug was also ibuprofen.

Good taste is the most important factor in medication compliance in pediatric age group. In a study in UK, three drugs containing paracetamol, ibuprofen and codeine have been compared and ibuprofen 
syrup has been the favorite drug in terms of the taste (9). However, in another study still in UK, paracetamol and ibuprofen containing drugs were compared and the flavors of drugs were appreciated equally ${ }^{(10)}$. Celebi et al. ${ }^{(11)}$ also have failed to find a significant difference between paracetamol and ibuprofen in their work. In our study, no significant differences were found between paracetamol and ibuprofen in accordance with previous studies.

The bitter taste of medicines may be masked by covering original medication (dragee, tablet, or capsule) with a layer or film of sugar in adults ${ }^{(8)}$. But, usually liquid formulations are manufactured for children as they are unable to swallow capsules and tablets ${ }^{(15)}$. Unfortunately, the bitter taste is more intense in liquid formulations. For this reason, sweeteners and flavorings are added to the formulation to mask the bitter taste and to facilitate intake ${ }^{(16)}$. In our study, although it was not statistically significant, the active ingredient of both the most popular and the least popular medication was ibuprofen. But their sweeteners and flavours were different from each other. Sodium saccharin, and sorbitol were used as sweeteners in the most popular drugs, when sucrose was used in the least popular one. Smith et al. ${ }^{(9)}$ reported that sucrose as a sweetener was not liked. Mennella et al. ${ }^{(6)}$ reported that the bitter taste of sucrose supresses the taste of many bitter substances, depending on both substances and the genetic diversity between people. Rate of compliance to the least- rated ibuprofen syrup was found as $88.6 \%$. When sorbitol and sodium saccharin were added as sweetener to the same substance, children liked the medication more and adherence rate increased to $96.7 \%$. This has suggested that the palatability of different brands/formulations of the same drugs put in the market by different companies may differ depending on their contents of sweeteners and flavors independent of the ingredients; as a result acceptability may vary. İnterestingly, compliance to the $250 \mathrm{mg} / \mathrm{scale}$ form of paracetamol, was observed as $100 \%$. It was thought that this is due to the fact that this drug was prescribed for older children.

It has been reported that our perception about taste of the food is in fact based on our sense of smell ${ }^{(17)}$ People can perceive the sense of only 5 different tastes with receptors on the tongue (sweet, sour, bitter, salty and umami) ${ }^{(18)}$. But, with the sense of smell, one can distinguish tens of thousands of different molecules from the air also. In fact, approximately $80-90 \%$ of taste perception is due to the sense of smell ${ }^{(19)}$. Similarly, our study revealed a strong and directional positive relationship between scent and taste scores given to the prescribed medication.

When children don't like the taste of the drug they may spit it or vomit ${ }^{(20)}$. This condition is less frequently seen as much as the taste gets better. It is also observed in our study that the spitting behavior significantly decreased $(p<0.05)$ as much as the scores for the taste and smell increased. Sometimes families need to provide additional food with drugs in order to convince the child to take the medicine. In addition, when the scores of taste and smell increased, the need for additional nutrients also significantly $(p<0.05)$ decreased in all groups.

El-Chaar et al. have shown that previous experience with liquid preparations does not affect the taste scores. Also in our study, child's previous use of the medication did not alter the taste scores. It has also been observed that demographic variables such as age, gender, economic status of the family or education have no effect on childrens' drug choice.

One of the limitations of this work is that it covers a limited area of Turkey. Thus genetic variation plays a role in taste perception, a more extensive study covering different regions could be more useful. Furthermore, our study includes sick children with high fever. The senses of taste and smell of these children may be damaged due to the diseases. This could also affect the results. However, considering that these medications are used by children who are already ill, this event can be regarded as an advantage for study. It has been reported that post-marketing palatability and acceptability studies can be performed on real patients ${ }^{(22)}$. Another point is that, in many children, many other medications are prescribed meanwhile. Antipyretics were taken the first and once the decision was made the treatment with other drugs continued to prevent scores being affec- 
ted by these drugs.

In conclusion, our results suggest that all ibuprofen and paracetamol preparations are overall easily acceptable drugs in terms of their palatability. Many of the pediatric formulations are tested by the adults but not by the children in the development stage, for ethical reasons ${ }^{(23)}$. Local studies have potentially significant impact on producing more palatable medicines for children and on reducing global child mortality ${ }^{(24)}$. Prescribing a drug with an enjoyable taste to a child will reduce the difficulties parents experience while giving the medication and will enhance the compliance of the patient to medication. Thus, the continuity of treatment will be provided and more successful clinical results will be obtained.

\section{Conflict of interest statement}

No conflict of interest has been declared by the authors.

\section{Funding statement}

The authors of this research did not receive any specific grant from any funding agency in the public, commercial, or not-for-profit sectors.

\section{REFERENCES}

1. Serwint JR, Thoma K, Dabrow SM, Hunt LE, Barratt MS, Shope TR, et al. Comparing patients seen in pediatric resident continuity clinics and national ambulatory medical care survey practices: a study from the continuity research network. Pediatrics. 2006;118:849-58.

Available from: http://www.ncbi.nlm.nih.gov/pubmed/16923927

2. Wong $T$, Stang $A S$, Ganshorn $H$, Hartling L, Maconochie IK, Thomsen AM, et al. Combined and alternating paracetamol and ibuprofen therapy for febrile children. Evidence-Based Child Health. 2014;9:675-729.

https://doi.org/10.1002/ebch.1978

3. Chiappini E, D'Elios S, Mazzantini R, Becherucci P, Pierattelli $\mathrm{M}$, Galli L, et al. Adherence among Italian paediatricians to the Italian guidelines for the management of fever in children: a cross sectional survey. BMC Pediatr. 2013;13:210. Available from: http://www.pubmedcentral.nih.gov/articlerender.fcgi ?artid $=3878332 \&$ tool=pmcentrez\&rendertype $=a$ bstract doi:10.1186/1471-2431-13-210.

4. Winzenburg G D-BS. Industry perspective on palatability testing in children-two case studies. 2009;435(2012):139-42. https://doi.org/10.1016/j.ijpharm.2012.05.057

5. Walsh J, Cram A, Woertz K, Breitkreutz J, Winzenburg G, Turner R, et al. Playing hide and seek with poorly tasting paediatric medicines : Do not forget the excipients. Adv Drug
Deliv Rev. 2014;73:14-33.

Available from: doi:10.1016/j.addr.2014.02.012.

6. Mennella JA, Reed DR, Mathew PS, Roberts KM, Mansfield CJ. "A spoonful of sugar helps the medicine go down": bitter masking by sucrose among children and adults. Chem Senses. 2015;40(1):17-25. https://doi.org/10.1093/chemse/bju053

7. Ivanovska AV, Carin MA. Pediatric drug formulations: A review of challenges and progress. 2015;134(2):361-72. https://doi.org/10.1542/peds.2013-3225

8. Mennella JA, Spector AC, Reed DR, Coldwell SE. The bad taste of medicines: Overview of basic research on bitter taste. Clin Ther. 2013;35(8):1225-46.

Available from: http://dx.doi.org/10.1016/j.clinthera.2013.06.007.

9. Smith CJ, Sammons HM, Fakis A, Conroy S. A prospective study to assess the palatability of analgesic medicines in children. 2012;655-63. https://doi.org/10.1111/j.1365-2648.2012.06050.x

10. McIntyre J, Hull D. Comparing efficacy and tolerability of ibuprofen and paracetamol in fever. Arch Dis Child [Internet]. 1996;74(2):164-7.

Available from: http://www.pubmedcentral.nih.gov/articlerender.fcgi ?artid $=1511501 \&$ tool=pmcentrez $\&$ rendertype $=a$ bstract.

https://doi.org/10.1136/adc.74.2.164

11. Celebi S, Hacimustafaoglu M, Aygun D, Arisoy ES, Karali $Y$, Akgoz S, et al. Antipyretic effect of ketoprofen. Indian J Pediatr. 2009;76(3):287-91. https://doi.org/10.1007/s12098-008-0234-z

12. Craig SR, Adams L V, Spielberg SP, Campbell B. Social Science \& Medicine Pediatric therapeutics and medicine administration in resource-poor settings: A review of barriers and an agenda for interdisciplinary approaches to improving outcomes q. Soc Sci Med. 2009;69(11):1681-90. Available from: http://dx.doi.org/10.1016/j.socscimed.2009.08.024

13. EMA. Reflection paper: Formulation of Choice for the Paediatric Population (EMEA/CHMP/PEG/194810/2005). Guideline. 2006; Available from: http://www.ema.europa. eu/ema/index.jsp?curl=pages/regulation/general/general_ content_000404.jsp\&mid=WC0b01ac0580029572. doi:EMEA/CHMP/PEG/194810/2005.

14. Giacoia GP, Taylor-zapata P, Zajicek A. Eunice Kennedy Shriver National Institute of Child Health and Human Development Pediatrics Formulation Initiative: Proceedings from the Second Workshop on Pediatric Formulations. CLITHE. 2012;34(11):S1-10.

Available from: http://dx.doi.org/10.1016/j.clinthera.2012.09.013

15. Pawar S, Kumar A. Issues in the formulation of drugs for oral use in children: role of excipients. Paediatr Drugs. 2002;4(6):371-9.

Available from: http://www.ncbi.nlm.nih.gov/ pubmed/12038873. doi:10.2165/00148581-200204060-00004.

16. Flanagan T, Tuleu C. Patient-centred pharmaceutical design to improve acceptability of medicines: Similarities and Differences in Paediatric and Geriatric Populations. 2014;1871-89. https://doi.org/10.1007/s40265-014-0297-2

17. Zampini M, Spence C. Assessing the role of visual and auditory cues in multisensory perception of flavor. The Neural Bases of Multisensory Processes. 2012.

Available from: http://www.ncbi.nlm.nih.gov/pubmed/22593877

18. Chandrashekar J, Hoon MA, Ryba NJP, Zuker CS. The receptors and cells for mammalian taste. Nature. 2006;444:28894. 
https://doi.org/10.1038/nature05401

19. Breer $H$. The sense of smell: Reception of flavors. Ann N Y Acad Sci. 2008;1126(0):1-6.

https://doi.org/10.1196/annals.1433.010

20. Matsui D. Current issues in pediatric medication adherence. Paediatr Drugs. 2007;9(5):283-8. https://doi.org/10.2165/00148581-200709050-00001

21. ElChaar GM, Mardy G, Wehlou K, Rubin LG. Randomized, double blind comparison of brand and generic antibiotic suspensions: II. A study of taste and compliance in children. Pediatr Infect Dis J. 1996;15(1):18-22.

https://doi.org/10.1097/00006454-199601000-00003
22. Kozarewicz P. Regulatory perspectives on acceptability testing of dosageformsinchildren. ElsevierBV.2014;469(2):245-8. Available from: http://dx.doi.org/10.1016/j.jpharm.2014.03.057.

23. Zajicek A, Fossler MJ, Barrett JS, Worthington JH, Ternik R, Charkoftaki G, et al. A Report from the pediatric formulations task force: Perspectives on the State of Child-Friendly Oral Dosage Forms. 2013;15(4):1072-81.

https://doi.org/10.1208/s12248-013-9511-5

24. Baguley D, Lim E, Bevan A, Pallet A, Faust SN. Prescribing for children - taste and palatability affect adherence to antibiotics : a review. 2012;293-7.

https://doi.org/10.1136/archdischild-2011-300909 